Article

\title{
The Possibility of Using the Probiotic Starter Culture Lacticaseibacillus rhamnosus LOCK900 in Dry Fermented Pork Loins and Sausages Produced Under Industrial Conditions
}

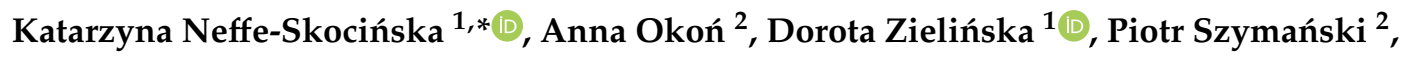 \\ Barbara Sionek ${ }^{1}$ and Danuta Kołożyn-Krajewska ${ }^{1}$ \\ 1 Institute of Human Nutrition Sciences, Warsaw University of Life Sciences (WULS), Nowoursynowska St. \\ 159C, 02-776 Warszawa, Poland; dorota_zielinska@sggw.edu.pl (D.Z.); barbara_sionek@sggw.edu.pl (B.S.); \\ danuta_kolozyn_krajewska@sggw.edu.pl (D.K.-K.) \\ 2 Prof. Wacław Dabrowski Institute of Agricultural and Food Biotechnology, Rakowiecka St. 36, \\ 02-532 Warsaw, Poland; anna.okon@ibprs.pl (A.O.); piotr.szymanski@ibprs.pl (P.S.) \\ * Correspondence: katarzyna_neffe_skocinska@sggw.edu.pl; Tel.: +48-225-937-067; Fax: +48-225-937-068
}

Received: 20 May 2020; Accepted: 19 June 2020; Published: 23 June 2020

Featured Application: It has been proven to be possible to use the probiotic starter culture for the production of dry fermented pork loins and sausages, under industrial conditions, with a guarantee of a high number of lactic acid bacteria (LAB), including probiotic strain and acceptable microbiological, physicochemical quality. Tested meat products can be stored in refrigerated, anaerobic conditions for 12 weeks.

\begin{abstract}
Probiotic strains used in the production of dry fermented meat should have appropriate technological properties comparable to traditional starter cultures used in meat processing. The problem arises when probiotics are added to a nonsterile food matrix, such as meat, and when it is uncertain whether these microorganisms have dominated the environment. The study aimed to assess the microbiological, physicochemical quality and safety of dry fermented pork loins and sausages with the addition of the probiotic starter culture LOCK900, produced under industrial conditions. Additionally, genetic identification by the PCR method and the presence of LOCK900 in the final products and after storage was done. It was demonstrated by the high number of LAB $\left(>6.0 \log \mathrm{cfu} \mathrm{g}^{-1}\right.$ ) and confirmed the presence in 90\% of the probiotic strain LOCK900 in the study of dry fermented meat products during all processing stages. Moreover, the safe and good quality loins and sausages can be stored in refrigerated, anaerobic conditions for 12 weeks, provided that optimized technological conditions are applied. In conclusion, the obtained results of the experiment showed that it is possible to create innovative functional dry fermented pork loins and sausages in a laboratory and then transfer the developed technology to full industrial conditions.
\end{abstract}

Keywords: probiotic starter culture; dry fermented meat; industrial production; microbiological quality; physicochemical quality; safety

\section{Introduction}

The definition of probiotic microorganisms was published in 2001 by the United Nations Food and Agriculture Organization (FAO) and the World Health Organization (WHO) expert team. They are defined as living microorganisms that, when administered in appropriate amounts, confer a health benefit on the host, including mainly on intestinal microflora [1-3]. In 2014, experts from ISAPP 
(International Scientific Association for Probiotics and Prebiotics) published grammatical corrections to the definition, retaining its sense and meaning [3]. Food containing a culture of probiotic microorganisms is extremely valuable for human health. However, the problem arises when probiotics are added to a nonsterile food matrix, such as meat, and when we are unsure whether these microorganisms have dominated the environment [4].

Dry fermented pork loins or sausages are meat products made of high-quality meat and animal fat with the possible addition of spices and herbs [5]. Currently, most of these types of products are produced in Mediterranean countries, but also in Germany, Austria, and Hungary. However, as a raw product, they require special attention in the aspect of microbiological safety and transformation of fats or proteins during production process and storage time [6-12]. Using starter cultures in the production of dry fermented meats is always intentional and aims at obtaining the specified sensory and microbiological characteristics of the end product. Currently, the production of commercial starter preparations use primarily lactic acid bacteria which show favorable technological effect.

In recent years, international scientific literature has included publications on the possibility of using probiotic bacteria in dry fermented meats' technology [13-17]. The authors showed that dry fermented meat should be characterized by a high degree of health safety and long shelf life, resulting in inhibiting the development of pathogenic microorganisms (e.g., Listeria monocytogenes) and limiting the formation of harmful compounds of protein transformation or fat oxidation [12,16,18]. However, no reports were found on the practical aspects of implementing production using probiotic bacteria in the meat industry. The available literature includes research on the analysis of microbiological and physicochemical quality of dry fermented meat products, produced using traditional starter cultures [13], not probiotic. Probiotic strains used in the production of dry fermented meat products must have appropriate technological properties comparable to traditional starter cultures that are used in meat processing. Therefore, the idea of using probiotic starter cultures in the meat production process causes many problems, in technological, microbiological, and analytical aspects $[4,19]$. The main difficulty is related not only to the method of adding strains to the raw meat material, but also to confirming its presence in the minimum number required for probiotic food. The selection of appropriate probiotics for meat product is difficult due to their sensitivity to technological conditions. As microorganisms isolated from the human digestive tract, these must dominate the nonsterile environment of the meat raw material.

Therefore, the additional value of the presented research is primarily the possibility of using probiotics as starter cultures in dry fermented meat products. An added value is also the transfer of technology developed in laboratory conditions on an industrial scale. It should be pointed that an effective technology for producing dry fermented meat products under industrial conditions is not commonly practiced in meat processing in the world.

The study aimed to assess the adaptability of raw meat fermentation technology using probiotic bacteria, developed in laboratory conditions, to industrial conditions. The criteria were the survival and the presence of a sufficiently high number of the probiotic strain used, health safety, and physicochemical quality of the products during refrigerated storage under vacuum conditions.

\section{Materials and Methods}

\subsection{Dry Fermented Meat Products' Manufacturing Process}

The meat material was carried out in strict accordance with the Polish law on guidelines for the protection of animals for slaughter and use, edited by the Polish Ministries of Agriculture and Rural Development. The used technology of the production of dry fermented meat products with probiotic starter culture addition was developed in earlier studies, in laboratory conditions [16,17,20-22].

The research material was produced under the industry conditions in the local Polish meat processing plant. Production rooms were previously properly disinfected and adapted only for the production of dry fermented meat products, not other cold meats. The plant staff were properly 
trained in hygiene principles and the specific production technology of dry fermented meat products. The plant staff were equipped with new, clean work wear, including gloves, protecting the raw meat material from hand contamination. Microbiological, physical, and chemical analyses were done after 21 days of the ripening process (time 0 ) and after 6 (time 1) and 12 (time 2) weeks of storage. Three series of experiments were performed under industry conditions. Two kinds of dry fermented meat products were produced (Table 1):

- Control LOINS, Control SAUSAGES-control samples of the study of dry fermented meat products without a probiotic starter culture LOCK900 addition;

- Probiotic LOINS, Probiotic SAUSAGES—samples of the study of dry fermented meat products with a probiotic starter culture LOCK900 addition.

Table 1. Dry fermented pork loins and sausages samples and their raw material composition (addition per kg of meat).

\begin{tabular}{ccccc}
\hline Kind of Sample & Glucose (g) & Sodium Ascorbate (g) & Spice Mix (g) & $\begin{array}{c}\text { Probiotic Starter } \\
\text { Culture LOCK900 (mL) }\end{array}$ \\
\hline Control LOINS & 5 & 0.5 & - & - \\
Probiotic LOINS & 5 & 0.5 & - & 2 \\
Control SAUSAGES & 5 & 0.5 & 13 & - \\
Probiotic SAUSAGES & 5 & 0.5 & 13 & 2 \\
\hline
\end{tabular}

\subsubsection{Manufacturing of Dry Fermented Pork Loins}

The presented technology of the production of dry fermented pork loins with probiotic starter culture addition was developed in earlier studies, under laboratory conditions $[16,17,20-22]$. The pork loins were excised at $24 \mathrm{~h}$ postmortem from half-carcasses chilled at $4 \pm 1^{\circ} \mathrm{C}$. Loin samples were cured using the "dry" method with the curing mixture in the quantity of $28 \mathrm{~g} \mathrm{~kg}^{-1}$. The curing process was conducted for $48 \mathrm{~h}$ at a temperature of $0{ }^{\circ} \mathrm{C}$. Then the starter mixture cultures $\left(2 \mathrm{~mL} \mathrm{~kg}^{-1}\right.$ of meat, containing $\left.6.0 \mathrm{log} \mathrm{cfu} \mathrm{mL}^{-1}\right)$, glucose $\left(5 \mathrm{~g} \mathrm{~kg}^{-1}\right.$ of meat), and sodium ascorbate $\left(0.5 \mathrm{~g} \mathrm{~kg}^{-1}\right.$ of meat) was added to each loin sample. Subsequently, loins were fermented at a temperature of $16{ }^{\circ} \mathrm{C}$ for 21 days in the fermentation chamber with a relative humidity of between $70 \%-75 \%$. After 10 days, the loins were cold smoked (alder wood, $30 \mathrm{~min} ., 30^{\circ} \mathrm{C}$ ). After 21 days of fermentation, the samples were vacuum-packed and stored at a temperature of $4{ }^{\circ} \mathrm{C}$ for 12 weeks.

\subsubsection{Manufacturing of Dry Fermented Sausages}

The presented technology of the production of dry fermented sausages with probiotic starter culture addition was developed in earlier studies, under laboratory conditions [16,17,20-22]. Meat and pork backfat were purchased from the meat manufacturer at $24 \mathrm{~h}$ postmortem. The sausages were prepared from the musculus biceps femoris and pork backfat in the proportion of 70:30 (w/w). The meat was cured using a $2.8 \%$ curing mixture ( $99.5 \%$ sea salt, $0.5 \%$ sodium nitrite) in relation to meat. The portion of cured pork meat was mixed separately with starter cultures $\left(2 \mathrm{~mL} \mathrm{~kg}^{-1}\right.$ of meat, containing $\left.6.0 \mathrm{log} \mathrm{cfu} \mathrm{mL} \mathrm{L}^{-1}\right)$, glucose $\left(5 \mathrm{~g} \mathrm{~kg}^{-1}\right.$ of meat), $5 \%$ of water, and spice: Garlic powder ( $5 \mathrm{~g} \mathrm{~kg}^{-1}$ of meat), black pepper (5 $\mathrm{g} \mathrm{kg}^{-1}$ of meat), and marjoram ( $3 \mathrm{~g} \mathrm{~kg}^{-1}$ of meat). The ingredients were added and mixed and then stuffed into natural casings. The sausages were matured according to the following procedure: $24 \mathrm{~h}$ at a temperature of $18^{\circ} \mathrm{C}$ and $85-92 \%$ relative humidity, followed by a gradual decrease in temperature to $17-16{ }^{\circ} \mathrm{C}$ and relative humidity to $75-80 \%$, and then the products were maintained under these conditions for 19 days, giving a total of 21 days of maturation. After 4 days the sausages were cold smoked (alder wood, $30 \mathrm{~min}$., $30^{\circ} \mathrm{C}$ ). Following maturation, the sausages were vacuum-packed and kept in a refrigerator $\left(4^{\circ} \mathrm{C}\right)$ for 12 weeks. 


\subsection{Preparation of the Probiotic Starter Culture}

The strain Lacticaseibacillus rhamnosus (formerly Lactobacillus rhamnosus) LOCK900 used in this study is known and fulfilled the criteria required for probiotic bacteria. The pure probiotic strain LOCK900 (Patent No: P.382760, strain deposit number: CP005454) came from a collection from the Technical University of Łódź in Poland [23]. The probiotic starter culture was prepared in laboratory conditions according to Neffe-Skocińska et al. [19]. The developed culture medium recipe allowed for the introduction of the pure inoculum of probiotic bacteria into the meat matrix without the addition of microbial media, and was not intended for human consumption. Preparation of the starting culture of the probiotic strain consisted of activating frozen bacteria, suspending them in food broth, and then inoculating the meat with them. The inoculum before being added to the raw meat was approximately $9.0 \mathrm{log}$ cfu $\mathrm{mL}^{-1}$. The probiotic starter culture was poured into sterile $100-\mathrm{mL}$ containers and transported to the processing meat plant in refrigeration conditions. Transportation time was not longer than $4 \mathrm{~h}$.

\subsection{Microbiological Analyses}

The microbiological analyses of pork loins and sausages were carried out immediately after the meat ripening period (time 0 ) also after 6 (time 1) and 12 weeks (time 2) of refrigerated storage, under anaerobic conditions. The analyses were carried out using the traditional plate method with dedicated culture media for a tested group of microorganisms: LAB (lactic acid bacteria; MRS agar-Man Rogosa Sharpe agar, Merck, Germany; incubation parameters $37{ }^{\circ} \mathrm{C}$ per $48 \mathrm{~h}$ ), ENT (microorganism from Enterobacteriaceae family; Mac Conkey agar Merck, Germany, incubation parameters $30^{\circ} \mathrm{C}$ per $24 \mathrm{~h}$ [24]), SALM (determining the presence of Salmonella bacteria in $25 \mathrm{~g}$ of the study products, XLD agar-Xylose Lysine Deoxycholate agar, Merck Germany, incubation parameters $37^{\circ} \mathrm{C}$ per $24 \mathrm{~h}$ [25]), LIST (determining the presence of Listeria monocytogenes bacteria in $25 \mathrm{~g}$ of the study products), ALOA agar-Agar Listeria according to Ottaviani and Agosti, Bio-Rad, USA and PALCAM agar-Polymyxin Acriflavin Lithium-chloride Ceftazidime Esculin Mannitol, LabM, UK, incubation parameters $37^{\circ} \mathrm{C}$ per $48 \mathrm{~h}$ [26]. All microbiological analysis was carried out in accordance with ISO (International Standards Organization) guidelines for the selected test, respectively. The results obtained are given in colony forming units per gram or milliliter of study product $\left(\mathrm{cfu} \mathrm{g}^{-1}\right.$ or $\left.\mathrm{cfu} \mathrm{mL}^{-1}\right)$.

\subsection{Confirmation of the Presence of the Probiotic Strain LOCK900 in Fermented Meat Products}

After 21 days of ripening dry fermented meat samples (time 0 ) and after 12 weeks of refrigerated storage, under anaerobic conditions, LABs were plated on MRS agar and 10-15 random colonies were isolated from each product plates. Colonies were plated separately on new MRS agar dishes and incubated at a temperature of $37^{\circ} \mathrm{C}$ for $48 \mathrm{~h}$. Initial identification of the Lacticaseibacillus genus was carried out and based on phenotypic studies (Gram method and catalase test; Merck, Germany).

For the isolation of genomic bacteria, the ExtractMe Bacteria DNA kit (Blirt S.A., Poland) was used, according to the manufacturer's manual. The genomic DNA of the pure culture of the L. rhamnosus LOCK900 strain was isolated as a positive control. For a negative control, distilled water was used.

The polymerase chain reaction (PCR) was carried out using the primer combination Y2:5'-CCCACTGCTGCCTCCCGTAGGAGT-3' and rham:5'-TGCATCTTGATTTAATTTTG-3' . The following amplification conditions were used: 1 cycle at $94{ }^{\circ} \mathrm{C}$ for $3 \mathrm{~min}, 45^{\circ} \mathrm{C}$ for $45 \mathrm{~s}, 72^{\circ} \mathrm{C}$ for $1 \mathrm{~min}$; then 30 cycles at $94{ }^{\circ} \mathrm{C}$ for $45 \mathrm{~s}, 45^{\circ} \mathrm{C}$ for $45 \mathrm{~s}, 72{ }^{\circ} \mathrm{C}$ for $1 \mathrm{~min}$; and, finally, 1 cycle at $94{ }^{\circ} \mathrm{C}$ for 45 $\mathrm{s}, 45^{\circ} \mathrm{C}$ for $45 \mathrm{~s}$, and $72{ }^{\circ} \mathrm{C}$ for $5 \mathrm{~min}$. The size of the target amplicons was $290 \mathrm{bp}$ (base pairs) [27]. PCR products were subjected to $1 \%$ agarose gel electrophoresis in a TAE buffer (Tris-acetate-EDTA). The gel was visualized under UV transillumination. 


\subsection{Physical and Chemical Analyses}

\subsubsection{The $\mathrm{pH}$ Determination}

The $\mathrm{pH}$ value was measured in a filtrate by mixing $10 \mathrm{~g}$ of a minced sample with $50 \mathrm{~mL}$ of de-ionized water for $1 \mathrm{~min}$, using a homogenizer (Bamix 200, Greifensee, Schweiz). The $\mathrm{pH}$ was measured with a digital pH meter (Mettler-Toledo, Seven Compact S220, Greifensee, Schweiz) equipped with a pH electrode (InLab Cool, Mettler-Toledo, Seven Compact S220, Greifensee, Schweiz). The pH readings were recorded at exactly $4 \mathrm{~min}$ after the insertion of the electrode into the sample. The $\mathrm{pH}$ meter was standardized with buffer solutions at $\mathrm{pH}$ 2.0, 4.0, 7.0, and 10.0.

\subsubsection{Oxidation-Reduction Potential (ORP) Measurements}

Ten grams of a minced sample was homogenized with $50 \mathrm{~mL}$ of deionized water for $1 \mathrm{~min}$, using a homogenizer (Bamix 200, Schweiz). The oxidation-reduction potential (ORP) measurements of the homogenates were carried out using a digital $\mathrm{pH}$ meter (Mettler-Toledo, Seven Compact S220, Greifensee, Schweiz) equipped with a redox electrode (InLab Redox Pro, Mettler-Toledo, Seven Compact S220, Greifensee, Schweiz).

\subsubsection{Lipid Oxidation}

The MDA (Malondialdehyde), the compound used as an index of secondary lipid peroxidation, was determined according to the procedure proposed by Pikul et al. [28]. The rose-pink color obtained by the reaction between MDA and 2-thiobarbituric acid was measured at $532 \mathrm{~nm}$ (Hitachi U-2900, Tokyo, Japan). The amount of TBARS (thiobarbituric acid-reactive substances) was expressed as milligrams of MDA per kilogram of a sample ( $\left.\mathrm{mg} \mathrm{MDA} \mathrm{kg}^{-1}\right)$.

\subsection{Statistical Analyses}

Three independent series of the experiment were performed (three productions under industrial conditions at three-month intervals, a random selection of raw meat material). Measurements were carried out in six replications for each sample. A two-way analysis of variance (ANOVA) at $p<0.05$ was performed to analyze the effect of the systems (probiotic LOINS vs. SAUSAGES) and the storage time. Tukey's test was conducted for a mean comparison. Differences were considered significant at $p<0.05$. All data were analyzed using Statistica version 13.1 (Statsoft Inc., Cracow, Poland).

\section{Results}

\subsection{LAB and the Probiotic Strain LOCK900 Presence in Fermented Meat Products}

Table 2 presents the results of the count of lactic acid bacteria in dry fermented meat products, produced under industrial conditions without and with the addition of the probiotic starter culture (L. rhamnosus LOCK900). Table 2 also presents the number of isolates identified as L. rhamnosus of dry fermented pork loins and sausages after production (time 0 ) and after 12 weeks of storage (time 2).

The high total number of lactic acid bacteria was determined in the probiotic samples of pork loins and sausages. In the case of pork loins, the count of LAB remained constant throughout the entire study period, approximately $7.0 \mathrm{log} \mathrm{cfu} \mathrm{g}^{-1}$. In the tested dry fermented sausages with probiotic starter culture addition, this number was significantly higher and averaged approximately $8.0 \mathrm{log} \mathrm{cfu} \mathrm{g}^{-1}$ during 6 weeks of storage.

A lower number of lactic acid bacteria was observed in control samples (without the addition of the probiotic starter culture). The total number of LAB was on average $6.0 \mathrm{log} \mathrm{cfu} \mathrm{g}^{-1}$ and during the refrigerated storage in a vacuum. For control loins, an increase by one logarithmic level was not found until 12 weeks. However, in the case of the control sausages, this increase occurred after 6 weeks of storage. 
A genetic identification of selected strains of $L A B$, isolated from the probiotic samples, was an additional confirmation that the added probiotic strain LOCK900 managed to dominate the microflora of the raw meat material. After the meat ripening process, the similarity of the LAB colony DNA material isolated from the study products to the DNA of the pure culture of the probiotic strain LOCK900 was demonstrated (Figure 1). It was found that among all the LAB isolates, $80 \%$ for loins and $84 \%$ for sausages gave the product (290 base pairs) similar to the product obtained from PCR when the DNA of the pure probiotic LOCK900 strain culture was used. Another comparison was made after the end of 12 weeks of storage of the dry fermented meat products. In this case, $92 \%$ (loins) and $94 \%$ (sausages) of the obtained PCR products gave the same product as the LOCK900 sample (Table 2).

Table 2. The count of lactic acid bacteria (LAB) and the number of isolates identified as L. rhamnosus of dry fermented pork loins and sausages after production (time 0), 6 (time 1) and 12 (time 2) weeks of storage.

\begin{tabular}{|c|c|c|c|}
\hline Samples $(n=12)$ & Time 0 & Time 1 & Time 2 \\
\hline & \multicolumn{3}{|c|}{ Number of LAB $\left(\log \mathrm{cfu}^{-1}\right)$} \\
\hline Control LOINS & $6.11^{\mathrm{aA}} \pm 0.53$ & $6.99^{\mathrm{aA}} \pm 0.67$ & $7.04^{\mathrm{aB}} \pm 0.60$ \\
\hline Probiotic LOINS & $7.12^{\mathrm{bA}} \pm 0.87$ & $7.54^{\mathrm{bA}} \pm 0.63$ & $7.17^{\mathrm{aA}} \pm 0.43$ \\
\hline Control SAUSAGES & $6.89^{\mathrm{aA}} \pm 0.86$ & $7.10^{\mathrm{aB}} \pm 0.95$ & $7.31^{\mathrm{aB}} \pm 0.96$ \\
\hline \multirow[t]{2}{*}{ Probiotic SAUSAGES } & $8.08^{\mathrm{bA}} \pm 0.97$ & $8.30^{\mathrm{bA}} \pm 0.87$ & $8.21^{\mathrm{bA}} \pm 0.09$ \\
\hline & \multicolumn{3}{|c|}{ Number of Isolates Identified as L. Rhamnosus (\%) } \\
\hline Probiotic LOINS & $80 \pm 6.67$ & not analyzed & $92 \pm 0.86$ \\
\hline Probiotic SAUSAGES & $84 \pm 7.69$ & not analyzed & $94 \pm 5.09$ \\
\hline
\end{tabular}

Explanatory notes: Number of LAB: Data are expressed as the mean \pm SD of $n=$ samples. Means in the same column followed by different lowercase letters represent significant differences $(p<0.05)$. Means in the same row followed by different uppercase letters represent significant differences $(p<0.05)$.

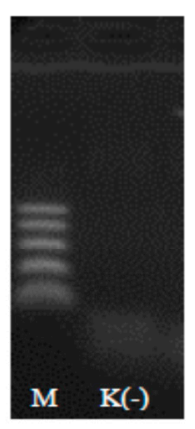

(a)

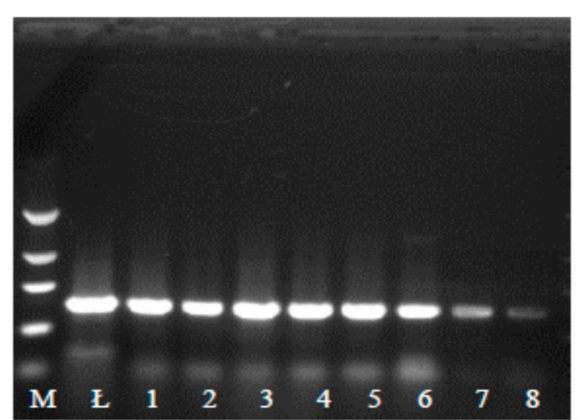

(b)

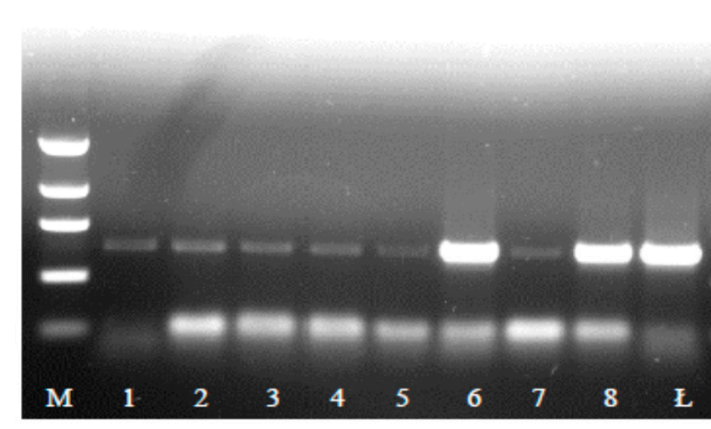

(c)

Figure 1. Example comparison of the PCR product (290 bp) of the L. rhamnosus LOCK900 strain ( $($ ) with other random isolated colonies of lactic acid bacteria (numbered 1-8) from stored dry fermented meat products: (a) negative control, (b) LOINS, (c) SAUSAGES; M-molecular weight DNA ladder 100-500 bp (base pairs).

\subsection{Microbiological Quality and Safety}

Table 3 presents the results of microbiological quality and safety of dry fermented loins and sausages, produced under industrial conditions with or without the addition of probiotic starter culture (L. rhamnosus LOCK900). 
values of the TBARS index of the control samples were found in comparison with the probiotic samples. The highest, statistically significant value of the TBARS index was found in the probiotic sausage $\left(1.51 \mathrm{mg} \mathrm{MDA} \mathrm{kg}^{-1}\right)$, while the lowest was in the control loin $\left(0.42 \mathrm{mg} \mathrm{MDA} \mathrm{kg}^{-1}\right)$.

Table 4. Physicochemical quality of dry fermented pork loins and sausages after production (time 0 ) and also after 6 (time 1) and 12 (time 2) weeks of storage.

\begin{tabular}{|c|c|c|c|}
\hline Samples $(n=12)$ & Time 0 & Time 1 & Time 2 \\
\hline & \multicolumn{3}{|c|}{ pH Value } \\
\hline Control LOINS & $5.69^{\mathrm{dB}} \pm 0.06$ & $5.42^{\mathrm{cA}} \pm 0.14$ & $5.47^{\mathrm{dA}} \pm 0.14$ \\
\hline Control SAUSAGES & $5.50^{\mathrm{cB}} \pm 0.07$ & $5.39^{\mathrm{cA}} \pm 0.06$ & $5.35^{\mathrm{cA}} \pm 0.05$ \\
\hline Probiotic LOINS & $4.96^{\mathrm{bB}} \pm 0.06$ & $5.01^{b C} \pm 0.02$ & $4.91^{\mathrm{bA}} \pm 0.03$ \\
\hline \multirow[t]{2}{*}{ Probiotic SAUSAGES } & $4.90^{\mathrm{aB}} \pm 0.03$ & $4.69^{\mathrm{aA}} \pm 0.06$ & $4.66^{\mathrm{aA}} \pm 0.07$ \\
\hline & \multicolumn{3}{|c|}{ ORP (mV) } \\
\hline Control LOINS & $\begin{array}{c}305.70^{\mathrm{aB}} \pm \\
17.15\end{array}$ & $294.90^{\mathrm{aB}} \pm 9.39$ & $276.00^{\mathrm{aA}} \pm 5.65$ \\
\hline Control SAUSAGES & $380.30^{\mathrm{dB}} \pm 4.15$ & $348.20^{\mathrm{bA}} \pm 6.21$ & $350.10^{\mathrm{cA}} \pm 3.99$ \\
\hline Probiotic LOINS & $316.30^{c C} \pm 1.92$ & $285.80^{\mathrm{aB}} \pm 3.44$ & $275.70^{\mathrm{aA}} \pm 9.43$ \\
\hline \multirow[t]{2}{*}{ Probiotic SAUSAGES } & $300.60^{\mathrm{bA}} \pm 3.70$ & $341.50^{\mathrm{bC}} \pm 9.29$ & $327.70^{\mathrm{bB}} \pm 7.70$ \\
\hline & \multicolumn{3}{|c|}{ TBARS (mg TDA kg $\left.{ }^{-1}\right)$} \\
\hline Control LOINS & $0.42^{\mathrm{aA}} \pm 0.11$ & $0.67^{\mathrm{bB}} \pm 0.16$ & $0.47^{\mathrm{aA}} \pm 0,08$ \\
\hline Control SAUSAGES & $0.90^{\mathrm{bA}} \pm 0.12$ & $1.13^{\mathrm{cB}} \pm 0.08$ & $1.32^{b C} \pm 0.07$ \\
\hline Probiotic LOINS & $1.34^{\mathrm{cB}} \pm 0.04$ & $0.48^{\mathrm{aA}} \pm 0.05$ & $0.46^{\mathrm{aA}} \pm 0,02$ \\
\hline Probiotic SAUSAGES & $1.51^{\mathrm{cB}} \pm 0.16$ & $0.50^{\mathrm{aA}} \pm 0.10$ & $0.49^{\mathrm{aA}} \pm 0.03$ \\
\hline
\end{tabular}

Explanatory notes: Data are expressed as the mean \pm SD of $n=$ samples. Means in the same column followed by different lowercase letters represent significant differences $(p<0.05)$. Means in the same row followed by different uppercase letters represent significant differences $(p<0.05)$.

\section{Discussion}

In the meat industry, a new concept is to design starter cultures containing lactic acid bacteria with probiotic properties, and then to use them to produce large-scale dry fermented cold meats. In addition to the possibility of growth and survival in the meat environment and the beneficial effects of bacteria with probiotic properties on the human body, an important aspect of using these microorganisms for the production of dry fermented meats is the ability to inhibit the growth of pathogenic microflora and stop any negative physicochemical changes concerning fats and proteins. Numerous studies have been carried out confirming that the use of probiotics in dry fermented meat production is possible [16,17,20-22]. It was also proven that Lacticaseibacillus rhamnosus LOCK900 (previously L. casei ŁOCK0900) is a well-studied probiotic strain and that it is possible to use as a starter culture in meat technology $[4,14,20,21]$.

One of the basic problems of using probiotic strains of lactic acid bacteria as starter cultures in the technology of dry fermented meat products is the nonsterile and non-uniform meat structure. $\mathrm{LAB}$, next to coagulase-negative staphylococci, is one of the main groups of microorganisms that are considered technologically important in the fermentation and maturation of meat products [18]. In the conducted research, it was shown that a significantly high total level of lactic acid bacteria in loins and sausages (range between 8.0 and $7.0 \log \mathrm{cfu} \mathrm{g}^{-1}$ ) with probiotic starter culture addition was achieved in comparison to controls. However, the difference between the number of LAB in the study of dry fermented meat products was most likely related to the consistency of the raw meat material (sausages (minced meat) and loins (not minced)), and also the possibility of migrating added probiotic bacteria deep into the product during the fermentation and ripening process. According to Kołożyn-Krajewska and Dolatowski [4], the different consistencies of individual muscles creates technological problems. During curing, fermentation, ripening, and storage, sarcoplasmic and myofibril proteins are hydrolyzed by microbial proteases and endogenous meat enzymes. Polypeptides, peptides, and free amino acids 
belong to compounds resulting from proteolysis [22]. In contrast, differences in fat on the surface of meat mean that the drying process is non-uniform and leads to differences between the muscles and, thus, to the inhibition or excessive growth of microorganisms [4,29].

The next difficulty is associated with determining the presence of the minimum number of probiotics per gram of a product $\left(6.0 \mathrm{log} \mathrm{cfu} \mathrm{g}^{-1}\right)[17,21]$. In the conducted research, the presence of the added probiotic strain LOCK900 in the study meat products was proven. The purpose was to confirm the presence of added probiotic bacteria, as well as to check the effectiveness of the used production technology, enabling the development of LOCK900 in two kinds of the raw meat matrix (minced and nonminced). The genetic identification was carried out in the finished product immediately after ripening (time 0 ) and after 12 weeks of storage (time 2). The research methodology consisted of comparing the obtained PCR reaction products for the control sample (pure culture of the strain LOCK900) with the amplification products of the genetic material of LAB isolated from the tested dry fermented pork lions and sausages. After the meat ripening process, the similarity of the LAB colony DNA material isolated from the study products to the DNA of a pure culture of the probiotic strain LOCK900 was demonstrated. The identification of lactic acid bacteria in meat products was previously carried out using phenotypic methods, e.g., API $50 \mathrm{CH}$ tests (bioMèrieux, USA) [30,31]. The results obtained in this way are not always satisfactory, and the identification concerns the bacterial species, not the strain [31]. A more accurate answer to the question of whether the probiotic strain used has developed, survived, and dominated the natural microflora in the meat environment can be obtained by combined culture-dependent and culture-independent methods, i.e., genetic engineering methods, including, for example, DNA polymerase chain reactions (PCR) or sequencing of the $16 \mathrm{~S}$ rRNA (ribosomal ribonucleic acid) gene characteristic of LAB bacteria $[5,9,32]$. In our study, a specific pair of primers for PCR reaction was used, designed to the V1 region of the 16S rRNA gene, which enables the differentiation of the Lacticaseibacillus rhamnosus species even from the closely related L. casei group [24]. The results of the plate count agar method showed a high overall LAB count in the tested meat products. It was found that approximately $90 \%$ of all LAB in the meat matrix was L. rhamnosus. Taking into account that $L$. rhamnosus is not a common species connected with the meat matrix, it can be concluded that the production technology designed in the laboratory and then scaled to the industrial conditions of dry fermented pork loins and sausages enabled the optimal growth and survival of the probiotic L. rhamnosus LOCK900 bacteria for 12 weeks from the end of the production process. The developed dry fermented meat products can be classified as functional foodstuffs.

One of the most important factors determining the quality and microbiological safety of food products is the conditions under which they were produced [13,33,34]. Health safety is the first criterion that a new food product must meet. In the second place is the definition of its quality. This problem is exacerbated when the developed food production technology is transferred from a laboratory and semitechnical conditions to industrial plants. Particular attention should be paid to products of animal origin, including raw products. Most pathogens that play a role in food-borne diseases are of animal origin [35]. The main problem in food hygiene is the contamination of raw meat material with pathogenic bacteria from the Enterobacteriaceae family, such as Salmonella spp., Escherichia coli, Proteus, and Klebsiella [36,37]. Noteworthy is also the pathogen Listeria monocytogenes, especially important in the case of ready-to-eat products of animal origin $[33,34]$. In the conducted studies, the total number of bacteria belonging to the Enterobacteriaceae family (ENT) was determined as a microbiological indicator of the hygienic state of the study meat products and, thus, the hygiene of the industrial production process. Microbiological analyses have shown a significant difference between the number of ENT in all study samples of loins and sausages during 12 weeks of storage. Based on the results, it was shown that there is a better bio-conserving effect of LAB, especially in the loins and sausages with probiotic starter culture LOCK900. The addition of probiotic starter culture LOCK900 had a positive effect on inhibiting the number of Enterobacteriaceae in the product and, finally, on eliminating them from the product. This dependence was observed in the control samples (native LAB microflora) until the 12th week of the study. This relationship is explained by other authors like a 
bio-conserving effect of lactic acid bacteria on meat products [18,38]. For example, Libera et al. [26] also showed that the number of Enterobacteriaceae in cured neck with LOCK900 addition decreased during the ripening and storage process $\left(<1.0 \mathrm{log} \mathrm{cfu}^{-1}\right)$. Whereas, Trzaskowska et al. [39] showed that the effects of type and number of used starter lactic acid bacteria on the production of dry fermented sausages ensured the health safety of the product. Lack of S. aureus, E. coli, and Enterobacteriaceae in all of the study sausages after six months of refrigeration is indicative of the extensive microbiological stability of the products. However, according to Tabanelli et al. [13], the interaction between selected starter cultures and environmental conditions drives the cell metabolisms towards results that can be beneficial or detrimental for the quality of the meat products. According to Wójciak et al. [40], Wójciak and Dolatowski [38], Kęska et al. [22], and also Ayyash et al. [17], it is clear that adding LAB starter cultures to meat not only provides new sensory properties and health benefits but also ensures greater product safety and stability. In contrast, probiotic starter cultures, as a result of their metabolic transformations, produce several bacteriostatic and bactericidal substances (e.g., lactic, acetic, formic acid, ethanol, or bacteriocin), thus inhibiting the development of spoiling and pathogenic microflora, including Gram-negative strains belonging to the family Enterobacteriaceae and Pseudomonaceae and such species as Listeria monocytogenes or Staphylococcus aureus; thereby naturally preserving dry fermented meat products $[2,8,41-43]$.

The addition of the probiotic starter culture LOCK900 and their bio-conservation effect improved the physicochemical stability of the study meat products. Through their metabolic transformations, LAB produces, among others, lactic acid, thereby reducing the $\mathrm{pH}$ of the finished meat product [43]. The low $\mathrm{pH}$ value was observed in fermented probiotic sausages $(4.90,4.69,4.66$, respectively), which also had a high LAB number $\left(8.08,8.30,8.21 \log \mathrm{CFU} \mathrm{g}^{-1}\right.$, respectively). The increase in acidity during fermentation and maturation affects the coagulation of muscle proteins, resulting in increased firmness and consistency of end products and the formation of a red color and characteristic taste $[14,19,44,45]$. The rapid decrease in $\mathrm{pH}$ contributes to inhibiting the development of adverse microflora and preventing the accumulation of biogenic amines $[4,46]$. The $\mathrm{pH}$ values of the inoculated sausages were lower than the pork loin after fermentation because the initial LAB inoculation led to a higher accumulation of lactic acid during ripening and consequently lowered the $\mathrm{pH}$ [40]. This indicated that the inoculation of probiotic cultures prompted carbohydrate breakdown and the accumulation of organic acids, mainly lactic acids, which led to a significantly faster acidification rate of the sausages than in the loins, which mirrored the reports by Keska et al. [22] and Zhao et al. [47]. The number of lactic acid bacteria in the product, and thus its $\mathrm{pH}$ value, indicates the evolution of the fermentation. The probiotic strain L. rhamnosus LOCK900 used for fermenting the loin and pork sausage produces significant amounts of organic acids modifying the $\mathrm{pH}$ of the meat product. A similar relationship has been observed by Libera et al. [20] during the production of dry fermented neck with the same starter probiotic culture LOCK900 with the addition of grape seed extract. The authors observed that the addition of probiotic culture to the neck matrix increased the acidity of the product during storage. The increase in the acidity of the products during refrigerated storage suggests that the addition of a probiotic had a beneficial effect on the fermentation process. Lower $\mathrm{pH}$ values in the probiotic loin compared to the control loin, which underwent spontaneous fermentation, showed that the probiotic strain used probably improved the fermentation process by producing more organic acids, especially lactic acid. These results correspond with the findings of other authors who confirmed the effectiveness of the inoculation with LAB for the acidification of dry-cured meat products [22,48]. Ayyash et al. [17] observed similar results in their studies in fermented camel sausage. The increase in $\mathrm{pH}$ values in the probiotic sausages after 6 weeks could be due to an increase in proteolytic peptides and amino acid and amines which have buffering effects on organic acids, which was induced by bacterial proteases [49] or decreases in the number of LAB [50].

The incorporation of probiotic culture to meat products had a significant $(p<0.05)$ effect on ORP at the time of storage. ORP of the probiotic loins reached at times 1 and 2 were significantly lower $(p<0.05)$ than the other samples. These results coincided with the findings of other authors $[22,40]$ who 
showed higher ORP for spontaneously fermented samples compared to loin and sausage inoculated with starter cultures. Kęska et al. [22] reported that the most significant effect of Lacticaseibacillus was observed at the initial storage period (28 days), where ORP was approximately 14-24 $\mathrm{mV}$ lower for samples with probiotic strain for the control $(293.38 \mathrm{mV})$. The increase in ORP values in the probiotic sausages after 6 weeks could be due to competing for nutrients and the ability to produce inhibitory substances (organic acids, hydrogen peroxide, and bacteriocins) or the changes in the number of LAB [50].

A significantly higher value of the TBARS index of probiotic samples after production could be due to the capacity of the L. casei LOCK900 for the production of $\mathrm{H}_{2} \mathrm{O}_{2}$, which, on the one hand, has a toxic effect on pathogens, but, on the other hand, has a pro-oxidative effect on food ingredients [40]. This is confirmed by other studies on raw maturing sausages and dry fermented necks with the participation of the analyzed strain $[20,40]$. TBARS values presented a decreasing trend, which, from an initial value after ripening of $1.34-1.51 \mathrm{mg} \mathrm{MDA} \mathrm{kg}^{-1}$, reached $0.48-0.50$ after 6 weeks and $0.46-0.49$ at the end of storage time for the probiotic pork loin and sausage batches, respectively. A significant decrease in the TBARS value, by $0.86 \mathrm{mg} M D A ~ k g^{-1}$, occurred in loin with a probiotic $(p<0.05)$, by $1.05 \mathrm{mg} \mathrm{MDA} \mathrm{kg}^{-1}$ - in probiotic sausage $(p<0.05)$ after six weeks of storage. The present study showed that the added probiotics inhibited lipid oxidation in loin and sausage meat during 12 weeks of cold storage. Chen et al. [51] and Sun et al. [52] demonstrated that the LAB had antioxidant activity and inhibition of lipid oxidation in fermented meat products. Therefore, this phenomenon could explain why the concentration of MDA did not continue to increase as Lacticaseibacillus was detected as being dominant in the cold storage stages.

Laboratory and semitechnical studies regarding the design of new meat products have been previously carried out under standardized conditions [16,17,20-22]. This applies to both strictly observed hygiene conditions, as well as the quantity and weighing of individual raw material additives. Particular attention should be paid to addition of a probiotic starter culture. In laboratory conditions, the probiotic strain was added to the meat matrix under sterility conditions (the equipment and qualifications of the people), which was not impossible in the production hall of the industrial plant. However, it was found that the developed technology for the production of two kinds of dry fermented meat products (pork loins (nonminced meat) and sausages (minced meat)) with the addition of the probiotic strain LOCK900 was successfully transferred to industrial conditions. Based on the results of this study and those by other authors, it can be stated that both the hygiene criterion of the production process and the criterion of food safety have been met. Moreover, the added value of manufactured meat products is in the use of the probiotic starter culture LOCK900 with pro-health and bio-conserving properties.

\section{Conclusions}

It was found that it is possible to use probiotic bacterial strains for the production of dry fermented meat products, with appropriate microbiological, physicochemical, and safety quality. A high number of LAB, including the $90 \%$ probiotic strain Lacticaseibacillus rhamnosus LOCK900, in dry fermented meat products during all processing stages was found. The developed dry fermented pork loin and sausages could be classified as functional products. However, nutrition research is necessary to definitely determine their health-promoting effects on the human organism. The added probiotics inhibited lipid oxidation in pork loins and sausages. Moreover, safe and good quality loins and sausages can be stored in refrigerated, vacuum environments for 12 weeks, provided that optimized technological conditions are applied. In conclusion, the obtained results of the study show that it is possible to create innovative, functional, dry fermented pork loins and sausages in a laboratory and then transfer the obtained technology to full industrial conditions. Additionally, it was proven how important the optimal selection and preparation of probiotic starter culture is with pro-health and bio-conserving properties for the production of dry fermented meat products. 
Author Contributions: Conceptualization, K.N.-S.; methodology, K.N.-S., D.Z., and A.O.; software, A.O.; validation, D.Z.; formal analysis, D.K.-K.; investigation, K.N.-S., D.Z., A.O., and B.S.; resources, K.N.-S., D.Z., and A.O.; data curation, K.N.-S., D.Z., A.O., and B.S.; writing-original draft preparation, K.N.S.; writing-review and editing, K.N.-S. and D.Z.; visualization, K.N.-S.; supervision, K.N.-S.; project administration, D.K.-K. and P.S.; funding acquisition, P.S. All authors have read and agreed to the published version of the manuscript.

Funding: This research received no external funding.

Acknowledgments: The authors sincerely thank Zbigniew J. Dolatowski (Prof. Wacław Dabrowski Institute of Agricultural and Food Biotechnology, Department of Meat and Fat Technology, Poland) for scientific and technology support during the research. The authors would also like to thank Katarzyna Sliżewska (Institute of Fermentation Technology and Microbiology, Poland) for access to the probiotic strain L. rhamnosus LOCK900 for conducting this study.

Conflicts of Interest: The authors declare no conflict of interest.

\section{References}

1. FAO/WHO. Guidelines for the Evaluations of Probiotics in Food; Report of a Joint FAO/WHO Working Group. Available online: http://www.fao.org/tempref/docrep/fao/009/a0512e/a0512e00.pdf (accessed on 5 April 2020).

2. Rivera-Espinoza, Y.; Gallardo-Navarro, Y. Non-dairy probiotic products. Food Microbiol. 2010, $27,1-11$. [CrossRef] [PubMed]

3. Hill, C.; Guarner, F.; Reid, G.; Reid, G.; Gibson, G.R.; Merenstein, D.J.; Pot, B.; Morelli, L.; Canani, R.B.; Flint, H.J.; et al. Expert consensus document: The International Scientific Association for Probiotics and Prebiotics consensus statement on the scope and appropriate use of the term probiotic. Nat. Rev. Gastroenterol. Hepatol. 2014, 11, 506-514. [CrossRef] [PubMed]

4. Kołożyn-Krajewska, D.; Dolatowski, Z.J. Probiotic meat products and human nutrition. Process. Biochem. 2012, 47, 1761-1772. [CrossRef]

5. Cocolin, L.; Rantsiou, K. Meat fermentation. In Handbook of Animal-Based Fermented Food and Beverage Technology, 2nd ed.; Hui, Y.H., Ed.; CRC Press: Boca Raton, FL, USA, 2012; pp. 533-535.

6. Pidcock, K.; Heard, G.M.; Henriksson, A. Application of non-traditional meat starter cultures in production of Hulgarian salami. Int. J. Food Microbiol. 2002, 76, 75-81. [CrossRef]

7. Papamanoli, E.; Tzanetakis, N.; Litopoulou-Tzanetaki, E.; Kotzekidou, P. Characterization of lactic acid bacteria isolated from a Greek dry-fermented sausage in respect of their technological and probiotic properties. Meat Sci. 2003, 65, 859-867. [CrossRef]

8. Työppönen, S.; Petaja, E.; Mattila- Sandholm, T. Bioprotectives and probiotics for dry sausages. Int. J. Food Microbiol. 2003, 83, 233-244. [CrossRef]

9. Klingberg, T.D.; Axelsson, L.; Naterstad, K.; Elsser, D.; Bude, B.B. Identification of potential starter cultures for Scandinavian-type fermented sausages. Int. J. Food Microbiol. 2005, 105, 419-431. [CrossRef]

10. Benito, M.J.; Martin, A.; Aranda, E.; Perez-Nevado, F.; Ruiz-Moyano, S.; Cordoba, M.G. Characterization and selection of autochthonous lactic acid bacteria isolated from traditional Iberian dry-fermented salchichon and chorizo sausages. J. Food Sci. 2007, 72, M193-M201. [CrossRef]

11. Rebucci, R.; Sangalli, L.; Fava, M.; Bersani, C.; Cantoni, C.; Baldi, A. Evaluation of functional aspects in Lactobacillus strains isolated from dry fermented sausages. J. Food Qual. 2007, 30, 187-201. [CrossRef]

12. Prado, N.; Sampayo, M.; González, P.; Lombó, F.; Díaz, J. Physicochemical, sensory and microbiological characterization of Asturian Chorizo, a traditional fermented sausage manufactured in Northern Spain. Meat Sci. 2019, 156, 118-124. [CrossRef]

13. Tabanelli, G.; Coloretti, F.; Chiavari, C.; Grazia, L.; Lanciotti, R.; Gardini, F. Effects of starter cultures and fermentation climate on the properties of two types of typical Italian dry fermented sausages produced under industrial conditions. Food Control. 2012, 26, 416-426. [CrossRef]

14. Wójciak, K.M.; Dolatowski, Z.J.; Kołożyn-Krajewska, D.; Trząskowska, M. The effect of the Lactobacillus casei ŁOCK 0900 probiotic strain on the quality of dry-fermented sausage during chilling storage. J. Food Qual. 2012, 35, 353-365. [CrossRef]

15. Kęska, P.; Stadnik, J. Taste-active peptides and amino acids of pork meat as components of dry-cured meat products: An in-silico study. J. Sens. Study 2017. [CrossRef] 
16. Pavli, F.G.; Argyri, A.A.; Chorianopoulos, N.G.; Nychas, G.J.E.; Tassou, C.C. Evaluation of Lactobacillus plantarum L125 strain with probiotic potential on physicochemical, microbiological and sensorial characteristics of dry-fermented sausages. LWT_Food Sci. Technol. 2020, 118, 108810. [CrossRef]

17. Ayyash, M.; Liu, S.Q.; Al Mheiri, A.; Aldhaheri, M.; Raeisi, B.; Al-Nabulsi, A.; Osaili, T.; Olaimat, A. In vitro investigation of health-promoting benefits of fermented camel sausage by novel probiotic Lactobacillus plantarum: A comparative study with beef sausages. LWT-Food Sci. Technol. 2019, 99, 346-354. [CrossRef]

18. Aymerich, T.; Martín, B.; Garriga, M.; Hugas, M. Microbial Quality and Direct PCR Identification of Lactic Acid Bacteria and Nonpathogenic Staphylococci from Artisanal Low-Acid Sausages. Appl. Environ. Microbiol. 2003, 69, 4583-4594. [CrossRef]

19. Neffe-Skocińska, K.; Okoń, A.; Kołożyn-Krajewska, D.; Dolatowski, Z. Amino acid profile and sensory characteristics of dry fermented pork loins produced with a mixture of probiotic starter cultures. J. Sci. Food Agric. 2017, 97, 2953-2960. [CrossRef]

20. Libera, J.; Latoch, A.; Wójciak, K.M. Utilization of Grape Seed Extract as a Natural Antioxidant in the Technology of Meat Products Inoculated with a Probiotic Strain of LAB. Foods 2020, 9, 103. [CrossRef]

21. Neffe-Skocińska, K.; Wójciak, K.M.; Zielińska, D. Probiotic microorganisms in dry fermented meat products. In Probiotics and Prebiotics in Human Nutrition and Health, 1st ed.; Rao, V., Rao, L.G., Eds.; InTech: Rijeka, Croatia, 2016; pp. 279-300.

22. Kęska, P.; Stadnik, J.; Wójciak, K.M.; Neffe-Skocińska, K. Physico-chemical and proteolytic changes during cold storage of dry-cured pork loins with probiotic strains of LAB. Int. J. Food Sci. Technol. 2020, 55, 1069-1079. [CrossRef]

23. Aleksandrzak-Piekarczyk, T.; Koryszewska-Bagińska, A.; Bardowski, J. Genome Sequence of the Probiotic Strain Lactobacillus rhamnosus (Formerly Lactobacillus casei) LOCK900. Genome. Announc. 2013, 1, e00640-13. [CrossRef]

24. ISO. Microbiology of the Food Chain-Horizontal Method for the Detection and Enumeration of Enterobacteriaceae-Part 2: Colony-Count Technique; ISO 21528-2:2017; International Organization for Standardization: Geneva, Switzerland, 2017.

25. ISO. Microbiology of the Food Chain-Horizontal Method for the Detection, Enumeration and Serotyping of Salmonella_Part 1: Detection of Salmonella spp.; ISO 6579-1:2017; International Organization for Standardization: Geneva, Switzerland, 2017.

26. ISO. Microbiology of the Food Chain-Horizontal Method for the Detection and Enumeration of Listeria monocytogenes and of Listeria spp.-_Part 1: Detection Method; ISO 11290-1:2017; International Organization for Standardization: Geneva, Switzerland, 2017.

27. Ward, L.J.H.; Timmins, M.J. Differentiation of Lactobacillus casei, Lactobacillus paracasei and Lactobacillus rhamnosus by polymerase chain reaction. Lett. Appl. Microbiol. 1999, 29, 90-92. [CrossRef] [PubMed]

28. Pikul, J.; Leszczyński, D.E.; Kummerow, F.A. Evaluation of three modified TBA methods for measuring lipidoxidation in chicken meat. Food Chem. 1989, 37, 1309-1315. [CrossRef]

29. Singh, V.P.; Pathak, V.; Verma, A.K. Fermented meat products: Organoleptic qualities and biogenic amines-A review. Am. J. Food Technol. 2012, 7, 278-288. [CrossRef]

30. Samappito, W.; Leenanon, B.; Levin, R.E. Microbiological Characteristics of "Mhom", a Thai Traditional Meat Sausage. Open Food Sci. J. 2011, 5, 31-36. [CrossRef]

31. Kröckel, L. Chapter 5-The role of lactic acid bacteria in safety and flavour development of meat and meat products. In Lactic Acid Bacteria-R \& D for Food, Health and Livestock Purposes, 1st ed.; Kongo, M., Ed.; InTech-Open Access Publisher: Rijeka, Croatia, 2013; Available online: http://dx.doi.org/10.5772/51117 (accessed on 5 April 2020). [CrossRef]

32. Zielińska, D.; Ołdak, A.; Rzepkowska, A.; Zieliński, K. Chapter 6-Enumeration and Identification of Probiotic Bacteria in Food Matrices. In Handbook of Food Bioengineering, Advances in Biotechnology for Food Industry, 1st ed.; Holban, A.M., Grumezescu, A.M., Eds.; Academic Press-Elsevier: Bucharest, Romania, 2018; pp. 167-196.

33. Muniz da Silva, A.C.; Pena, P.O.; Pflanzer Júnior, S.B.; Silva do Nascimento, M. Effect of different dry aging temperatures on Listeria in nocua as surrogate for Listeria monocytogenes. Meat Sci. 2019, 157, 107884. [CrossRef] 
34. Olanya, O.M.; Hoshide, A.K.; Ijabadeniyi, O.A.; Ukukua, D.O.; Mukhopadhyayd, S.; Niemira, B.A.; Ayenie, O. Cost estimation of listeriosis (Listeria monocytogenes) occurrence in South Africa in 2017 and its food safety implications. Food Control. 2019, 102, 231-239. [CrossRef]

35. Busani, L.; Scavia, G.; Luzzi, I.; Caprioli, A. Laboratory surveillance for prevention and control of foodborne zoonoses. Ann. Ist. Super. Sanita 2006, 42, 401-404.

36. Gwida, M.; Hotzel, H.; Geue, L.; Tomaso, H. Occurrence of Enterobacteriaceae in Raw Meat and in Human Samples from Egyptian Retail Sellers. Int. Sch. Res. Not. 2014. [CrossRef]

37. Paterson, D.L. Resistance in Gram-negative bacteria: Enterobacteriaceae. Am. J. Med. 2006, 119, S20-S28. [CrossRef]

38. Wójciak, K.M.; Dolatowski, Z.J. Effect of acid whey on nitrosylmyoglobin concentration in uncured fermented sausage. LWT-Food Sci. Technol. 2015, 64, 713-719. [CrossRef]

39. Trząskowska, M.; Kołożyn-Krajewska, D.; Wójciak, K. Microbiological quality of raw-fermented sausages with Lactobacillus casei LOCK0900 probiotic strain. Food Control. 2014, 35, 184-191. [CrossRef]

40. Wójciak, K.M.; Karwowska, M.; Dolatowski, Z.J. Use of acid whey and mustard seed to replace nitrites during cooked sausage production. Meat Sci. 2014, 96, 750-756. [CrossRef] [PubMed]

41. Ammor, M.S.; Mayo, B. Selection criteria for lactic acid bacteria to be used as functional starter cultures in dry fermented sausages. An update. Meat Sci. 2007, 76, 138-146. [CrossRef] [PubMed]

42. Coll, C.F.; Giannuzzi, N.E.; Zaritzky, N.E. Mathematical modeling of microbial growth in ground beef from Argentina. Effect of lactic acid addition, temperature and packaging film. Meat Sci. 2008, 79, 509-520.

43. Muthusamy, K.; Soundharrajan, I.; Srisesharam, S.; Kim, D.; Kuppusamy, P.; Lee, D.L.; Choi, K.C. Probiotic Characteristics and Antifungal Activity of Lactobacillus plantarum and Its Impact on Fermentation of Italian Ryegrass at Low Moisture. Appl. Sci. 2020, 10, 417. [CrossRef]

44. Lorenzo, J.M.; Gomez, M.; Fonseca, S. Effect of commercial starter cultures on physicochemical characteristics, microbial counts and free fatty acid composition of dry-cured foal sausage. Food Control. 2014, 46, 382-389. [CrossRef]

45. Lorenzo, J.M.; Sarriés, M.V.; Tateo, A.; Polidori, P.; Franco, D.; Lanza, M. Carcass characteristics, meat quality and nutritional value of horsemeat: A review. Meat Sci. 2014, 96, 1478-1488. [CrossRef]

46. Macedo, R.E.F.; Pflanzer, O.S.; Gomes, C.L. Probiotic Meat Products. In Probiotic in Animals, 1st ed.; Rigobelo, I.C., Ed.; InTech-Open Access Publisher: Rijeka, Croatia, 2012; Available online: http://www. intechopen.com/books/probiotic-in-animals (accessed on 5 April 2020). [CrossRef]

47. Zhao, L.H.; Jin, Y.; Ma, C.W.; Song, H.; Li, H.; Wang, Z.; Xiao, S. Physico-chemical characteristics and free fatty acid composition of dry fermented mutton sausages as affected by the use of various combinations of starter cultures and spices. Meat Sci. 2011, 88, 761-766. [CrossRef]

48. Okon, A.; Stadnik, J.; Dolatowski, Z.J. Effect of probiotic bacteria on antiradical activity of peptides isolated from dry-cured loins. CyTA—J. Food 2017, 15, 382-390. [CrossRef]

49. Ruiz-Moyano, S.; Martín, A.; Benito, M.J.; Hernández, A.; Casquete, R.; Córdoba, M.G. Application of Lactobacillus fermentum HL57 and Pediococcus acidilactici SP979 as potential probiotics in the manufacture of traditional Iberian dry-fermented sausages. Food Microbiol. 2011, 28, 839-847. [CrossRef]

50. Essid, I.; Hassouna, M. Effect of inoculation of selected Staphylococcus xylosus and Lactobacillus plantarum strains on biochemical, microbiological and textural characteristics of a Tunisian dry fermented sausage. Food Control. 2013, 32, 707-714. [CrossRef]

51. Chen, Q.; Kong, B.; Sun, Q.; Dong, F.; Liu, Q. Antioxidant potential of a unique LAB culture isolated from Harbin dry sausage: In vitro and in a sausage model. Meat Sci. 2015, 110, 180-188. [CrossRef] [PubMed]

52. Sun, F.; Kong, B.; Chen, Q.; Han, Q.; Diao, X. N-nitrosoamine inhibition and quality preservation of Harbin dry sausages by inoculated with Lactobacillus pentosus, Lactobacillus curvatus and Lactobacillus sake. Food Control. 2017, 73, 1514-1521. [CrossRef]

(C) 2020 by the authors. Licensee MDPI, Basel, Switzerland. This article is an open access article distributed under the terms and conditions of the Creative Commons Attribution (CC BY) license (http://creativecommons.org/licenses/by/4.0/). 